\title{
Economics of multifunctional forestry in the Sámi people homeland region
}

\section{Parkatti, Vesa-Pekka}

$2021-10$

Parkatti , V-P \& Tahvonen , O 2021 , ' Economics of multifunctional forestry in the Sámi people homeland region ', Journal of Environmental Economics and Management, vol. 110 , 102542 , pp. 102542 . https://doi.org/10.1016/j.jeem.2021.102542

http://hdl.handle.net/10138/334340

https://doi.org/10.1016/j.jeem.2021.102542

cc_by

publishedVersion

Downloaded from Helda, University of Helsinki institutional repository.

This is an electronic reprint of the original article.

This reprint may differ from the original in pagination and typographic detail.

Please cite the original version. 


\title{
Journal of Environmental Economics and Management
}

\section{Economics of multifunctional forestry in the Sámi people homeland region}

\author{
Vesa-Pekka Parkatti, Olli Tahvonen \\ Department of Forest Sciences, Department of Economics, University of Helsinki, P.O. Box 27, FI-00014, Helsinki, Finland
}

\section{A R T I C L E I N F O}

\section{JEL classification:}

Q23

Q28

Keywords:

Indigenous peoples

Sámi

Continuous cover forestry

Optimal rotation

Carbon sequestration

Reindeer husbandry

Subarctic forestry

Forest economics

\begin{abstract}
A B S T R A C T
We study forestry in the Sámi people homeland to understand an ongoing conflict between conventional forestry and maintaining forests as reindeer pastures vital for indigenous Sámi livelihood. Conventional logging affects pastures by creating stand densities suboptimal to lichen growth and by decreasing old-growth forest areas, both of which are essential to reindeer survivability during the subarctic winter. Our model includes timber production, carbon sequestration, externalities on reindeer husbandry, and optimization between rotation forestry and forestry with continuous forest cover. We show that the profitability of conventional forestry relies on utilizing existing forests, an outcome we label as forest capital mining. By varying the carbon price between $€ 0$ and $€ 60$ per $\mathrm{tCO}_{2}$ and assuming a $3 \%$ interest rate, we show that continuous cover forestry, which better preserves pastures, is always optimal. A carbon price of $€ 60-€ 100$ chokes off timber production. Given the present management practices and an oldgrowth forest as the initial state, the carbon choke price decreases to $€ 14-€ 20$. Our economic analysis on maintaining old-growth forest versus conversion to timber production is an alternative to the frequently applied approach based on carbon debts and carbon payback periods.
\end{abstract}

\section{Introduction}

Forests are a prime example of natural resources that offer contributions beyond their extractive values. These values should be included in economic analyses despite the difficulties in quantifying their typically nonmarket realizations. The setup complicates further, when forests are concurrently vital to indigenous people and industrial logging. According to recent estimates, indigenous groups manage $11 \%$ of the world's forests and $80 \%$ of its biodiversity (Parrotta and Trosper 2012; Schuster et al., 2019). Highly divergent views occur on every continent such as industrial logging practices vs. First Nations traditions in Canada and USA, forest-related cultures and logging in India, and traditional multipurpose forestry vs. pulp plantations in Latin America.

The Sàmi people are the only indigenous people in the European Union and populate the northernmost parts of Finland, Sweden, Norway, and northwestern Russia. Long-lasting conflicts have occurred between the reindeer herders and government-operated forestry (Turunen et al., 2020). Information on forestry private and social profitability would be essential for finding a route toward solutions, but no strict estimates exist. Profitability figures are critical since forestry is close to its external margin in Upper

We thank the associate editor and two referees for the comments and succestions. This study was financed by the Academy of Finland (1330835), NordForsk (76915) and Maj and Tor Nessling Foundation (201800263). Additionally, we thank Aino Assmuth for the discussion and help concerning the carbon storage model and Jouni Siipilehto for providing us the Motti stand simulator output.

* Corresponding author.

E-mail addresses: vesa-pekka.parkatti@helsinki.fi (V.-P. Parkatti), olli.tahvonen@helsinki.fi (O. Tahvonen). 
Lapland, and the relative significance of other forest functions are exceptionally high. Since Hartman (1976), forest economics has recognized forest value besides timber, but further achievements in multifunctional forestry has proved difficult (Amacher 2015). Our aim is to carry out such an analysis, and our case may help reach reconciliation in other parts of the world as well.

Economic studies on industrial logging and maintaining boreal or subarctic forest environments in favorable conditions for mammals, such as reindeer or caribou, are scarce apart for a few theoretical models (Parks et al., 2002). According to Ruppert et al. (2016) and Martin et al. (2017), forestry has caused fragmentation and loss of old-growths in the Canadian boreal region. As a result, the woodland caribou is listed as a threatened species. The authors develop a spatial optimization approach that meets a fixed industrial timber demand and minimizes the effects on caribou habitat. Their results show that optimized spatial allocation of logging greatly increases (30\%) the suitable caribou habitat. However, their setup is not fully flexible and leaves open the social optimality of existing harvesting targets and the monetary implications of various spatial logging solutions (cf. Yemshanov et al., 2021).

A number of studies investigate the relationship between forestry and reindeer husbandry in Sweden and Finland (Berg et al., 2008; Korosuo et al., 2014; Sandström et al., 2016; Turunen et al., 2020). This literature shares a common understanding of a rapid decrease in lichen-rich winter grazing grounds, i.e. resources that are the primary limitation to reindeer husbandry. Sweden has experienced a loss of $30-50 \%$ of these grazing grounds during the last part of the 20th century. Studies observe an inherent conflict between reindeer pasture conditions and intensive forest management that aim to increase timber production. The problems follow both from clearcutting and excessively dense stands later during the rotations. This readily suggests that solutions could be searched from changes in forest management methods and land allocation for various purposes.

The forests in Finnish Upper Lapland consist of Scots pine (Pinus sylvestris L.) stands, are characterized by high public ownership (70\%) managed by a state-owned enterprise. The harsh climate causes slow forest growth, ca. $1.5 \mathrm{~m}^{3}$ per hectare per year (Natural Resources Institute Finland 2020). Hyppönen (2002) estimates the yearly net income per hectare in the Lapland region to be ca. 10\% of the income in southern Finland. This rough estimate supports studying the profitability of industrial timber production in Upper Lapland and how it compares with other forest functions such as reindeer husbandry, carbon storage, tourism, conservation, hunting, and berry/mushroom picking (Ahtikoski et al., 2011), which are not directly supported by market incentives.

Husbandry of the semi-domesticated reindeer is an integral part of the Sàmi culture, social life, and livelihood, and Sàmis are the only indigenous people recognized in the constitutions of Finland, Norway, Sweden, and the European Union (European Union 2005). The cultural transition from deer hunting toward reindeer pastoralism dates back to A.D. 1000, if not earlier (Bergman et al., 2008). Presently, reindeer are mainly used for meat production, albeit hides, bones, and antlers are important material for clothing and handicrafts. In Sweden, the cultural heritage value of reindeer husbandry has been estimated as high (Bostedt and Lundgren 2010). Families own reindeer privately and have grazing rights on private and public lands that are common property as pastures. This has led to a common interpretation of labeling reindeer pastures as a "tragedy of commons". However, this has been rejected by referring to the old Sàmi institution called siida, which refers to a group of reindeer-owners who locally organize and manage husbandry, including herd size and pasture conditions (Bjøklund 1990). Presently, husbandry is organized as herding districts, with similar functions and an average area per district is ca. $2300 \mathrm{~km}^{2}$ in Finland. The herds graze rather freely in the district areas but are gathered together twice or thrice per year for counting, calf marking, and harvesting.

The Reindeer Husbandry Act (848/1990) of Finland states that other land-use forms should not cause remarkable disadvantage to reindeer husbandry on government lands in Upper Lapland. The exact interpretation of this legislation has not been clarified in count, but while the effect of each logging operation on pastures may be minor, their cumulative effect over decades may become high. If reindeer populations are not simultaneously decreased, the outcome is the degradation of reindeer pastures, and there is ongoing debate of whether this pasture degradation is caused by reindeer population levels or land-use changes. Approximately $35 \%$ of the forests in certain districts have been logged during the past 50 years, with strong pressure on remaining pastures (Saijets 2019).

Terrestrial and arboreal lichen (lichen in trees) form vital winter energy sources for both caribou and reindeer. In British Columbia, clearcut harvesting is incompatible with the conservation of (red-listed) mountain caribou, which prefer old-growth forests as winter habitat. A number of Canadian empirical studies suggest that forestry based on partial cuttings, i.e. continuous cover forestry (CCF), maintains both ground and arboreal lichen and may even increase their abundance compared to old-growth forests (Stevenson and Coxson 2007, 2015). Consequently, recommendations have been developed for using CCF instead of clearcutting within the mountain caribou habitant.

Based on Nordic satellite observations, field measurements of lichen biomass, and on reindeer movements in various site types (Kumpula et al. 2007, 2014), logging implies a temporary decrease in arboreal and ground lichen abundance and pasture value in reindeer husbandry. By applying bioeconomic estimates on pasture values in reindeer management (Tahvonen et al., 2014), we can include the logging externality as a cost in optimizing socially optimal forestry. Based on Canadian experiments and Nordic observations that a forest basal area between $10-15 \mathrm{~m}^{2} \mathrm{ha} \mathrm{C}^{-1}$ is optimal for ground lichen, similar externalities are clearly less evident when applying CCF.

Upper Lapland forestry has been based on clearcuts on both private and public lands, and according to guidelines for public forests (Metsähallitus 2014) in Sámi regions, forestry should mainly be conducted as rotation forestry (RF) based on the thinning of small-diameter trees ("thinning from below") followed by seedling felling at the end of rotation. Seedling felling is close to clearcutting but maintains some residual trees to enhance natural regeneration. RF is the dominant management method in Nordic countries, but Tahvonen and Rämö (2016) suggest that the economic competitiveness of CCF compared to RF is surprisingly high, especially when growth conditions are low, as is the case in Upper Lapland. Assmuth et al. (2018) show that pricing carbon favors CCF when simultaneously optimizing both timber production and carbon sequestration. Given this setup, we ask how flexible alternatives, such as CCF, carbon sequestration, and externalities on reindeer husbandry, determine socially preferable forestry in Upper Lapland and how it compares to official management guidelines. As carbon sequestration may increase stand density, which is detrimental to lichen at 
excessive levels, the consequences of carbon storage to reindeer husbandry remain unclear. Another open question is how externalities on reindeer husbandry and carbon sequestration alter the economic decision of land conversion from old-growth to timber production, a question presently studied by applying concepts such as carbon depth and payback period (Fargione et al., 2008).

Our model is a statistical-empirical size-structured model that allows the joint optimization of wood production and carbon sequestration. It includes completely flexible optimization between RF and CCF and is a substantial extension of the classic rotation model applied by Samuelson (1976), Hartman (1976), and Van Kooten et al. (1995) in both its theoretical structure and empirical realism. Externalities on reindeer husbandry are included as costs occurring after each seedling felling.

When optimizing pure timber production with a $1 \%$ interest rate, the optimal regime is RF with a very long rotation, while a $3 \%$ interest rate causes CCF to become optimal with the thinning of large-diameter trees. Including externalities on reindeer husbandry implies the optimality of CCF with a $1 \%$ interest rate as well. Adding carbon sequestration lengthens the rotation and CCF steady-state harvesting intervals, directs harvests to larger trees, and increases stand volume toward levels more favorable to reindeer husbandry. A high carbon price causes harvesting to stop completely, and forests are then utilized solely as carbon storage and reindeer pastures. While a similar discontinuation of timber production is possible in the generic rotation model (Van Kooten et al., 1995), we extend the result and show that the choke-off price is higher in models with thinning and CCF/RF choice.

In addition to studying optimal forest management solutions, we analyze the consequences of conventional forest management by following silvicultural guidelines that are applied on public lands in the Sàmi region. We show that the positive net present value (NPV) of conventional management is based on harvesting existing forests that, in most cases, are "free gifts of nature", i.e. old-growth stands that have generated without any management effort. Because of the questionable economically sustainable properties, we label this form of forest management as "forest capital mining". Given an old-growth as the initial state, the choke price of carbon turns out to be much lower compared to the conventional assumption of bare land or managed forest. Switching from conventional forestry to thinning from above, longer rotations, and CCF would increase the profitability of forestry and offer a promising route for integrating forestry, carbon storage, and maintaining pasture conditions. Finally, we discuss our economic approach and the extensive literature initiated by Fargione et al. (2008), which applies the concepts of carbon debt and payback period to analyze the consequences of converting old-growth forest to plantations.

\section{Optimizing timber production, carbon, and externalities on reindeer husbandry}

Let the number of trees in size class $s$, at the beginning of period $t$, be denoted by $x_{s t}, s=1, \ldots, n, t=t_{0}, t_{0}+1, \ldots, T$, and write $\mathbf{x}_{t}=x_{1 t}$, $x_{2 t}, \ldots, x_{n t}$. The fraction of trees that move to the next size class during each period $t$ is $0 \leq \alpha_{s}\left(\mathbf{x}_{t}\right) \leq 1, s=1, \ldots, n-1$. Similarly, the fraction of trees that die during each period is denoted as $0 \leq \mu_{s}\left(\mathbf{x}_{t}\right) \leq 1, s=1, \ldots, n$. Thus, the fraction of trees that remain in the same size class during period $t$ is $1-\alpha_{s}\left(\mathbf{x}_{t}\right)-\mu_{s}\left(\mathbf{x}_{t}\right) \geq 0$. The number of trees harvested from size class $s$ at the end of period $t$ is $h_{s t}, s=1, \ldots, n$, $t=t_{0}, t_{0}+1 \ldots, T$. Write $\mathbf{h}_{t}=\left(h_{1 t}, h_{2 t}, \ldots, h_{n t}\right)$. In addition, let $\varphi\left(\mathbf{x}_{t}\right)$ describe the ingrowth of trees (natural regeneration) into the smallest size class. The stand develops according to the difference equation system.

$$
\begin{aligned}
& x_{1, t+1}=\varphi\left(x_{t}\right)+\left[1-\alpha_{1}\left(x_{t}\right)-\mu_{1}\left(x_{t}\right)\right] x_{1 t}-h_{1 t}, t=t_{0}, \ldots, T \\
& x_{s+1, t+1}=\alpha_{s}\left(x_{t}\right) x_{s t}+\left[1-\alpha_{s+1}\left(x_{t}\right)-\mu_{s+1}\left(x_{t}\right)\right] x_{s+1, t}-h_{s+1 . t}, s=1, \ldots, n-1, t=t_{0}, \ldots, T
\end{aligned}
$$

We use seven size classes based on diameter breast height $d_{s}, s=1, \ldots, 7$, ranging from $75 \mathrm{~mm}$ to $375 \mathrm{~mm}$ (midpoint) in 50-mm intervals. Each size class $s$ has specific sawlog and pulpwood volumes given by $v_{1 s}$ and $v_{2 s}, s=1, \ldots, 7$., respectively (Appendix A, Table A1). These size-class-specific sawlog and pulpwood volumes correspond to volumes in the Finnish Motti stand simulator (Matala et al., 2003). Local roadside prices $\left(€ / \mathrm{m}^{3}\right)$ for sawlog and pulpwood are denoted by $p_{1}$ and $p_{2}$, respectively (Appendix A, Table A2). The revenues per harvest $R\left(\mathbf{h}_{t}\right)$ are specified as

$$
R\left(h_{t}\right)=\sum_{s=1}^{n}\left(v_{1 s} p_{1}+v_{2 s} p_{2}\right) h_{s t} .
$$

Following Nurminen et al. (2006), separate variable harvesting costs for thinning $C_{t h}$ and seedling felling $C_{s f}$ are given as.

$$
C_{i}=C_{i 0} C_{i 1} \sum_{s=1}^{7} h_{s t}\left(C_{i 2}+C_{i 3} v_{s}-C_{i 4} v_{s}^{2}\right)+C_{i 5}\left[C_{i 6} \sum_{s=1}^{7} h_{s t} v_{s}+C_{i 7}\left(\sum_{s=1}^{7} h_{s t} v_{s t}\right)^{0.7}\right], i=t h, s f
$$

The parameter values $C_{i s}, i=t h, s f, s=1, \ldots, 7$ are specified in Appendix A, Table A3 and imply that harvesting costs are higher with thinning compared to seedling felling. We also include fixed costs of harvesting $\left(C_{f}=€ 250\right.$ ha $\left.^{-1}\right)$ that consist of both logging machinery transportation and harvest operation planning costs. The fixed cost is set at a smaller level compared to e.g. Parkatti and Tahvonen (2020) because of the larger average forest management unit in Upper Finland.

Based on the practices by Metsähallitus (2014) for Sàmi homeland regions, we specify stand regeneration as seed regeneration and seedling felling. Thus, the initial stand consists of 50 seed trees in size class $22.5 \mathrm{~cm}$ and 30 trees in size class $27.5 \mathrm{~cm}$. These trees have been left unharvested in the previous seedling felling to generate new saplings. We assume that these seed trees are harvested 25 years after seedling felling. After accounting for the growth of these trees during the 25 -year period, their stumpage value (roadside prices net of harvesting cost) equals $1512 € \mathrm{ha}^{-1}$. Seed tree regeneration has seldom been included in forest economic models (e.g. in Assmuth et al., 2018) but is necessary here to be in line with the management choice actually applied. 
Seed tree regeneration requires some active management effort, i.e. harrowing at $t=0$ and tending of the seedling stand at $t=25$. Based on the most recent statistics available, we set these costs to equal $€ 169 \mathrm{ha}^{-1}$ and $€ 385 \mathrm{ha}^{-1}$, respectively (Natural Resources Institute Finland 2020).

Clearcuts and seedling felling hamper reindeer husbandry through forest environment fragmentation and by decreasing both ground lichen and arboreal lichen (lichen growing on trees), both of which are vital winter forage for reindeer (Stevenson and Coxson 2007, 2015, Berg at al. 2008). Based on an expert estimate by Kumpula (2014, personal communication), we assume that pasture value after seedling felling is decreased by $80 \%$ for the first 30 years and by $50 \%$ for up to 80 years. This estimate is based on satellite observations and field measurements on lichen biomass and on reindeer movements in various site types (Kumpula et al. 2007, 2014). In Jonsson Čabrajič et al. (2010) and Sandström et al. (2016), the optimal tree density for ground lichen is estimated as $10-15 m^{2} h a^{-1}$. According to the forest growth model applied here, the $15 \mathrm{~m}^{2}$ density is reached 65 years after seedling felling. After recognizing that lichen density reacts to changes in growing conditions with a delay, this estimate is in line with our assumption regarding the effects of felling on lichen availability. The pasture value of an old-growth hectare with lichen is approximately $€ 30$ ha $^{-1}$ per year (Tahvonen et al., 2014; Pekkarinen et al. 2015, 2020). This allows us to include an approximation for the external effects of seedling felling on reindeer husbandry by including $€ 1056$ (interest rate 1\%) or $€ 629$ (interest rate 3\%) in the costs occurring after seed tree felling. Canadian studies by Stevenson and Coxson (2007, 2015) suggest that RF and CCF thinnings do not have similar effects on ground and especially arboreal lichen. Harvesting residues left after any harvesting operation affect ground lichen and its availability, but this effect is too difficult to quantify.

The existence of fixed harvesting cost in both thinning and seedling felling implies that we must include a binary variable $\delta_{t}: Z \in$ $\{0,1\}, t=t_{0}, \ldots, T$ and define both harvests and fixed harvesting costs by Boolean operators $h_{s t}=\delta_{t} h_{s t}$ and $C_{f}=\delta_{t} C_{f}$, respectively. When $\delta_{t}=1$, a fixed cost $C_{f}$ occurs and $h_{s t}$ is freely optimized. In contrast, when $\delta_{t}=0$, both $C_{f}$ and $h_{s t}$ equal zero.

In addition to timber revenues, we include a social value of carbon sequestration by applying the specifications in Assmuth et al. (2018). Let $p_{c} \geq 0$ denote the social price of carbon in $€ \mathrm{tCO}_{2}{ }^{-1}$. Total commercial stem volume at the beginning of period $t$ is denoted by $\omega_{t}=\sum_{s=1}^{n} x_{s t}\left(v_{1 s}+v_{2 s}\right)$. This is converted into stem dry mass using a density factor $\rho=0.3729$ in tons per $m^{3}$ (Lehtonen et al., 2004). The stem dry mass is converted to whole-tree dry mass (including foliage, branches, bark, stumps, and roots) by an expansion factor $\eta=1.8909$ (Lehtonen et al., 2004). Thus, the total stand biomass equals $\rho \eta \omega_{t}$ in tons of dry mass. The carbon content of one ton of dry mass is given by $\theta=1.8333$ in $\mathrm{CO}_{2}$ (Pihlainen et al., 2014). The dry mass content in sawlog and pulpwood harvests are denoted by $y_{1 t}=\rho \sum_{s=1}^{n} h_{s t} v_{1 s}$ and $y_{2 t}=\rho \sum_{s=1}^{n} h_{s t} \nu_{2 s}$, respectively. Dead tree matter of the stand consists of both naturally dead trees and harvesting residues. The dry mass of dead tree matter from natural mortality is $y_{3 t}=\rho \eta \sum_{s=1}^{n} \mu_{s}\left(\mathbf{x}_{t}\right) x_{s t}\left(v_{1 s}+v_{2 s}\right)$, and the dry mass of harvest residue is $y_{4 t}=(\eta-1)\left(y_{1 t}+y_{2 t}\right)$. Let $g_{j}, j=1,2,3,4$ present the annual decay rates of sawlog, pulpwood, and dead tree matter, respectively. The decay rates are set to $g_{1}=0.0706, g_{2}=0.4707$ (Liski et al., 2001), and to compute parameter $g_{3}=g_{4}=$ 0.1019, we apply Mäkinen et al. (2006), Palviainen et al. (2004, 2010), and Shorohova et al. (2008). The present value of future emissions from product and dead tree mass decay are given by $p_{c} \beta_{r j}$, where $\beta_{r j}=g_{j} /\left(g_{j}+r\right), j=1, \ldots, 4$ (Assmuth et al., 2018) where $r$ is the rate of interest. Thus, the value of the net carbon sequestration at $t=t_{0}, \ldots, T$ is

$$
Q\left(x_{t}, h_{t}\right)=p_{c} \theta\left[\rho \eta\left(\omega_{t+1}-\omega_{t}\right)+\sum_{j=1}^{4}\left(1-\beta_{r j}\right) y_{j t}\right]
$$

Denote the period length by $\Delta$ and the discount factor by $b^{\Delta}=1 /(1+r)^{\Delta}$. Let $W$ denote the present value of harvesting the seed trees net of the cost of harrowing and tending of the seedling stand and the external cost of reindeer husbandry. Taken together, the problem is to

$$
\max _{\left.\left\{h_{s t}, \delta_{t}, T \in t_{0}, \infty\right)\right\}} J\left(x_{t_{0}}\right)=\frac{W+\sum_{t=t_{0}}^{T}\left[R\left(h_{t}\right)-C_{t h}\left(h_{t}\right)-C_{s f}\left(h_{t}\right)-\delta_{t} C_{f}\right] b^{\Delta(t+1)}+\sum_{t=0}^{T} Q\left(x_{t}, h_{t}\right) b^{\Delta(t+1)}}{1-b^{\Delta(T+1)}}
$$

subject to (1), (2), and.

$$
\begin{aligned}
& h_{s t}=\delta_{t} h_{s t}, s=1, \ldots, n, t=t_{0}, \ldots, T \\
& x_{s, T+1}=\widehat{x}_{s, T+1}, s=1, \ldots, n \\
& x_{s, t_{0}}, \text { given, } s=1, \ldots, n,
\end{aligned}
$$

where $T \in\left[t_{0}, \infty\right)$ and the non-negativity conditions $x_{s t} \geq 0, h_{s t} \geq 0, t=t_{0}, \ldots, T, s=1, \ldots, n$ must hold. Restriction (8) specifies the seed trees left at the end of rotation and harvested 25 years after seedling felling. Following the recommendations by Metsähallitus (2014), we require 80 seed trees to be left at the seedling felling at $T$ and specify ( 8 ) as $\widehat{x}_{s, T+1}=0, s=1,2,3,6,7, \widehat{x}_{4, T+1}=50$ and $\widehat{x}_{5, T+1}=30$. At 
$t_{0}$ (45 years), the stand state is given as $\mathbf{x}_{t_{0}}=[1750,0, \ldots, 0]$.

Additionally, we analyze outcomes of conventional forest management. In these cases, all the optimization variables of problems (6)-(9) are determined by silvicultural instructions. Another variant is an old-growth forest as the initial state instead of a seed tree -regenerated state, as specified in (9). In these cases, we are interested in whether immediate land conversion of an old-growth stand to timber production (optimal or conventional) yields a positive outcome. This is evaluated by

$$
\widehat{J}=R\left(h_{t_{0}}\right)-C_{s f}\left(h_{t_{0}}\right)-\delta_{t} C_{f}+Q\left(x_{t_{0}}, h_{t_{0}}\right)+J\left(x_{t_{0}}\right),
$$

where the initial harvest is restricted by the requirement to leave the seed trees specified in (8). Applying ( $\left.6^{\prime}\right)$ with the case $\widehat{J}>0$ implies a positive outcome of the conversion and relies on the assumption that an old-growth forest has stable wood volume and is not a carbon sink or source. This is in line with Finnish principles for greenhouse gas inventories, where no growth in timber volume implies a zero carbon sink (Statistic Finland 2021). An extension of (6)-(9) and (6') in any initial forest state and optimization of management alternatives thereafter (Tahvonen and Rämö 2016; Malo et al., 2021) requires data on initial forest tree size-class structure, which is not available.

\section{Forest growth models and calibration}

\subsection{Ecological growth model for a pure Scots pine forest}

Bollandsås et al. (2008) and Pukkala et al. (2013) include models that are potentially suitable and openly published ecological models with natural regeneration for Fennoscandian forests and include parameter values that allow model calibration for various growth conditions. In the following, we present the properties of the Bollandsås et al. (2008) model, as a calibrated version of their model will be applied in the optimization.

The proportion of size class $s$ trees moving to size class $s+1$ during the next 5-year period in the Bollandsås et al. (2008) model is given as:

$$
\alpha_{s}\left(x_{t}\right)=q^{-1}\left(25.543+0.0251 d_{s}-5.660 \cdot 10^{-5} d_{s}^{2}-0.216 \beta_{s}\left(x_{t}\right)+0.698 S I-0.123 \beta\left(x_{t}\right)-0.336 L A T\right)
$$

where $\alpha_{s}\left(\mathbf{x}_{t}\right)$ is obtained by dividing the 5-year diameter growth ( $\mathrm{mm}$ ) of size class $s$ by the width of size class $q$ (50 mm) (Bollandsås 2008). The basal area of the stand $\left(\mathrm{m}^{2}\right.$ ha $\left.{ }^{-1}\right)$ is denoted by $\beta$ and specified as either $\beta\left(\mathbf{x}_{t}\right)=\sum_{s=1}^{n} \gamma_{s} x_{s}$ (symmetric competition) or $\beta_{s}\left(\mathbf{x}_{t}\right)=\sum_{i=s+1}^{n} \gamma_{s} x_{s}, s=1 . ., n-1$ (asymmetric competition), where $\gamma_{s}$ is the basal area $\left(\mathrm{m}^{2}\right)$ of a single tree in size class $s$. Parameter LAT (latitude) is set to $69.36^{\circ} \mathrm{N}$, to represent Finnish Upper Lapland. Parameter SI is the height (m) of the dominant trees at a stand age of 40 years. The proportion of trees in size class $s$ that die due to natural mortality in the next 5-year period according to Bollandsås et al. (2008) is given as:

$$
\mu_{s}\left(x_{t}\right)=\left[1+\exp \left(-\left(-1.808+0.027 d_{s}+3.300 \cdot 10^{-5} d_{s}^{2}+0.055 \beta\left(x_{t}\right)\right)\right)\right]^{-1}
$$

Finally, the number of naturally regenerated trees that grow into the smallest size class (ingrowth) during the next 5-year period according to the Bollandsås et al. (2008) model is given as:

$$
\varphi\left(\mathbf{x}_{t}\right)=\frac{67.152 \beta\left(\mathbf{x}_{t}\right)^{-0.076}}{1+\exp \left[0.452+0.062 \beta\left(\mathbf{x}_{t}\right)\right]}
$$

\subsection{Model calibration}

We calibrate the model by Bollandsås et al. (2008) by applying output data from the Finnish Motti stand simulator for an average-fertility pine stand (Vaccinium type). The Motti stand simulator is a widely used decision-support tool by the Natural Resources Institute Finland (Salminen et al., 2005). It is based on large inventory data sets covering all of Finland (Matala et al., 2003), but as the source code is not fully open, we cannot use the model directly for optimization purposes.

We specify the Bollandsås et al. (2008) model SI parameter to obtain the volume development to represent the volume development of the Motti stand simulator (without thinning). Because Motti does not include ingrowth, we set ingrowth (3) to zero in the calibration. A similar calibration is performed for the Pukkala et al. (2013) model by applying a range of different temperature sums. ${ }^{1}$ Fig. $1 \mathrm{~b}$ shows that the Pukkala et al. (2013) model does not produce long-term stand volume development similar to the development by Motti. Fig. 1a shows that stand volume development with the Bollandsås et al. (2008) model and SI of 9 m is initially slightly lower, and in the long run slightly higher, compared to stand volume development produced by Motti. However, overall, the stand volume developments are closest when setting $S I=9 m$.

When stand volume developments in Fig. $1 \mathrm{a}$ and $\mathrm{b}$ are compared to actual stand volumes in Upper Lapland old-growth forests, they turn out rather high because highest per hectare volumes fall below $200 \mathrm{~m}^{3} \mathrm{ha}^{-1}$ (Paikkatietoikkuna 2017). This difference may follow from the fact that Motti simulates managed forests, while present actual old-growth forests are naturally generated without active

\footnotetext{
${ }^{1}$ For applying the Pukkala et al. (2013) model, see Parkatti et al. (2019) and Parkatti and Tahvonen (2020).
} 
(a)

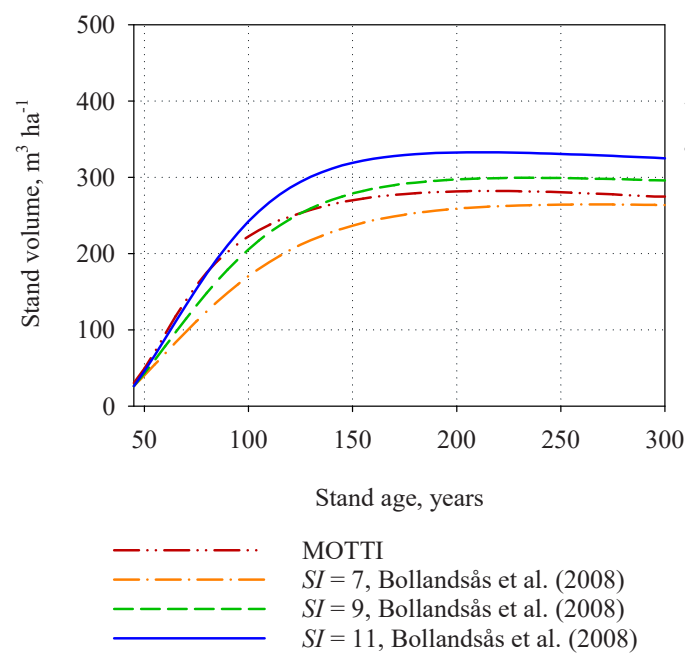

(b)

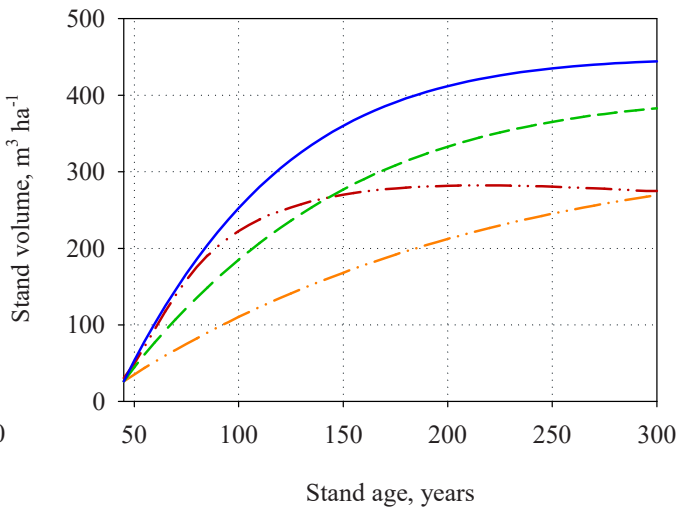

$-\cdots-\cdots-\cdots \quad$ MOTTI

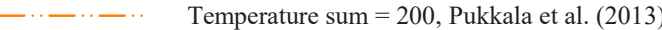

- - - - - Temperature sum $=400$, Pukkala et al. (2013)

Temperature sum $=600$, Pukkala et al. $(2013)$

Fig. 1. a,b: Comparing stand volume developments of the Bollandsås et al. (2008) (a) and Pukkala et al. (2013) (b) models to the development by Motti stand simulator. Note: $S I=$ height of dominant trees at the age of 40 years.

(a)

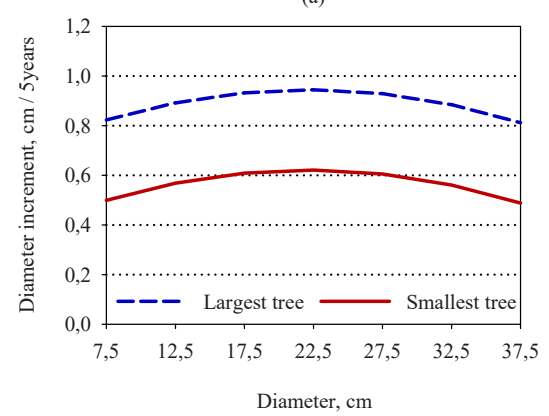

(b)

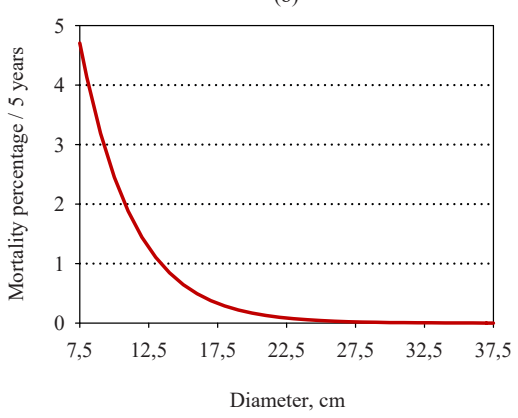

(c)

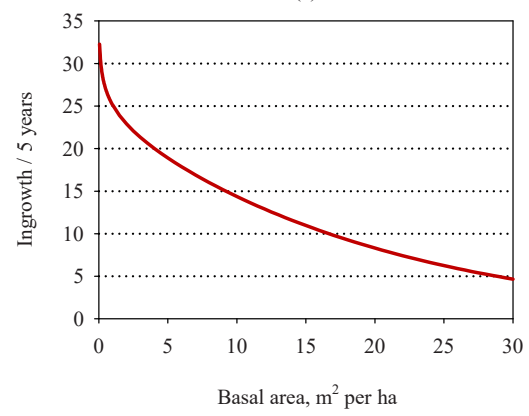

Fig. 2. a-c: Scots pine diameter increment (a), mortality (b), and ingrowth (c) with the calibrated Bollandsås et al. (2008) model. Note: Basal area in (a) and (b) equals $15 \mathrm{~m}^{2} \mathrm{ha}^{-1}$.

\section{management.}

Fig. 2a-c show the characteristics of the calibrated Bollandsås et al. (2008) model, and in Fig. 2a trees reach their peak growth at approximately $22.5 \mathrm{~cm}$ in diameter. Note that the position of the trees in the size-class structure strongly affects growth. The probability of natural mortality decreases as a tree grows (Fig. 2b). Ingrowth (natural regeneration) increases as stand basal area decreases, albeit ingrowth remains low (Fig. 2c).

\section{Computational methods}

The optimization problem (1) - (2) and (6)-(9) is a tri-level problem, in which the choice of rotation length $T$ is the highest-level problem, optimizing harvest timing $\delta_{t}: Z \in\{0,1\}, t=t_{0}, t_{0}+1, \ldots$ the middle-level problem, and size-class-specific harvesting intensity decisions $h_{s t}, s=1, \ldots, n, t=t_{0}, t_{0}+1, \ldots$ the lowest-level problem. The optimization is carried out using AMPL programming language and Knitro optimization software (version 10.3). Given a rotation length $T$, harvest timing is solved using generic algorithms explained in Sinha et al. (2017), while the harvesting intensities are solved with Knitro interior and active set algorithms. The rotation 
level is adjusted until a maximum objective functional value is found. If the maximum value exists with a rotation level between $T \in$ $[80,250]$, the optimal rotation is taken as finite and the management regime as RF. In contrast, if the NPV does not saturate when $T$ is increased, the optimal solution is CCF. The optimal infinite-time CCF solution is computed by optimizing up to seven transition harvests (both timing and intensities) before reaching an optimized steady-state harvesting interval. Using an Intel ${ }^{\circledR}$ Xeon ${ }^{\circledR}$ E5-2643 v3@3.40GHZ, 24 logical processors computer, the approximation of the infinite-horizon solution takes approximately $12 \mathrm{~h}$ to solve.

\section{Results and discussion}

We first solve optimal rotation without thinning, as a reality check, and to obtain a simple reference point for solutions with optimized thinning. Next, we optimize thinning simultaneously with rotation and then compute the outcome if a solution is determined by conventional guidelines. This is continued with an analysis of converting an old-growth to timber production. Finally, we discuss the sustainability properties of forestry and forestry without timber production.

\subsection{Optimal solutions without thinning}

In line with both theoretical studies (Van Kooten et al., 1995) and studies applying empirical models (Pihlainen et al., 2014), the optimal rotation is shortened by a higher interest rate and lengthened by a higher carbon price (Table 1). Including an external effect on reindeer husbandry lengthens a rotation by $0-20$ years. With a $3 \%$ interest rate, externalities decrease the NPV to - $€ 39$. A higher carbon price increases the NPV, while the NPV from timber production decreases, revealing the cost of carbon storage. With a 3\% (1\%) interest rate, a carbon price of $€ 40 \mathrm{tCO}_{2}^{-1}\left(€ 60 \mathrm{tCO}_{2}{ }^{-1}\right)$ causes rotation to become infinite, i.e. forest is utilized solely as carbon storage and reindeer pastures. As the carbon price increases, the discounted carbon sequestration increases and obtains a maximum when no harvesting takes place. With finite rotations, the mean annual yield varies between $1.7 / \mathrm{m}^{3}$ and $2.2 / \mathrm{m}^{3}$. The average harvesting costs are $€ 7.3 / \mathrm{m}^{3}$. This corresponds rather well with the average clearcut harvesting cost of $€ 8.1 / \mathrm{m}^{3}$ (Strandström 2018).

As management is based on seed felling and regeneration, the NPVs in Table 1 do not correspond to the bare land value (BLV) in the classic optimal rotation model. Seedling felling leads to 25 -year postponement of harvesting the seed trees. During this period, the seed trees (cf. Section 2) grow, while the net revenues are realized later. Saving the seed trees in seedling felling decreases the net revenue by $€ 1203$ but harvesting the seed trees 25 years later yields (undiscounted) revenues equal to $€ 1512$. The present value of the latter is included in the NPVs of Table 1 , but not the cost of saving the initial seed trees. Thus, the BLVs are obtained by subtracting $€ 1203$ from the NPVs of Tables 1, i.e. without carbon sequestration and with (without) externalities on reindeer husbandry, the BLVs equal $€ 961$ $(€ 2525)$ and $-€ 1242(-€ 572)$ with interest rates of $1 \%$ and $3 \%$, respectively, and obtain zero value with (without) externalities when the interest rate is $1.4 \%(2.1 \%)$.

No empirical data exist on the actual BLVs but when forest value is required in various official circumstances, the value in Lapland is set to $€ 50-30 \mathrm{ha}^{-1}$ assuming an interest rate between 1 and $2 \%$ (Mäki 2013). The average annual net revenues per hectare in the whole Lapland area in 2018 were $€ 33-36$ (Natural Resources institute Finland 2020) while the corresponding figures with 95- and 110-year rotation periods are $€ 49$ and $€ 57$. Additionally, timber prices in Upper Lapland are lower than the average price level in the whole Lapland area, suggesting that the results in Table 1 somewhat overestimate the profitability of pure timber production in Upper Lapland. Reasons behind this difference include the low cost of seed tree regeneration compared to methods actually applied, ${ }^{2}$ the fast growth predicted by the Motti simulation model, and the optimization setup applied here.

Table 1

Optimal solutions without thinning.

\begin{tabular}{|c|c|c|c|c|c|c|}
\hline $\begin{array}{l}\text { Interest rate } \\
r, \%\end{array}$ & $\begin{array}{l}\text { Price of carbon, } € \\
\mathrm{CO}_{2}^{-1}\end{array}$ & $\begin{array}{l}\text { NPV, } € \\
\text { ha }^{-1}\end{array}$ & $\begin{array}{l}\text { NPV, pure timber } \\
\text { production, } € \text { ha }^{-1}\end{array}$ & $\begin{array}{l}\text { Discounted } \mathrm{CO}_{2} \text { sequestration, } \\
\mathrm{tCO}_{2} \mathrm{ha}^{-1}\end{array}$ & $\begin{array}{l}\text { Mean annual yield, } \\
\mathrm{m}^{3} \mathrm{ha}^{-1}\end{array}$ & $\begin{array}{l}\text { Rotation, } \\
\text { years }\end{array}$ \\
\hline \multirow[t]{3}{*}{1} & 0 & $\begin{array}{l}2164 / \\
3728\end{array}$ & $3712 / 3728$ & $75 / 70$ & $2.2 / 2.2$ & $115 / 110$ \\
\hline & 20 & $\begin{array}{l}3820 / \\
5269\end{array}$ & $3430 / 3603$ & $91 / 83$ & $2.1 / 2.2$ & $135 / 125$ \\
\hline & 40 & $\begin{array}{l}5867 / \\
7160\end{array}$ & $2505 / 2906$ & $116 / 106$ & $1.7 / 1.9$ & $180 / 160$ \\
\hline \multirow[t]{3}{*}{3} & 0 & $-39 / 631$ & $631 / 631$ & $29 / 29$ & $2.2 / 2.2$ & $95 / 95$ \\
\hline & 20 & $608 / 1255$ & $542 / 569$ & $36 / 34$ & $2.2 / 2.2$ & $125 / 120$ \\
\hline & 40 & $\begin{array}{l}1391 / \\
2021\end{array}$ & $369 * / 369 *$ & $41 / 41$ & $0 / 0$ & $\infty / \infty$ \\
\hline
\end{tabular}

Note: Results given as with/without external effects on reindeer husbandry. *Positive NPV is caused by harvesting the initial seed trees.

\footnotetext{
${ }^{2}$ The BLVs for official purposes (Mäki 2013) assume a regeneration cost of $€ 1505-€ 1063$ (interest rate 1\%) and $€ 1329-€ 888$ (interest rate $3 \%$ ). Our regeneration costs are $€ 494$ and $€ 834$ with interest rates $1 \%$ and $3 \%$.
} 


\subsection{Solutions with optimal thinning}

The solution is CCF (Table 2) given optimized thinning, no carbon pricing, and a 1\% interest rate. However, without externalities the solution would be RF, with a long, 215-year rotation. Including carbon pricing yields RF but with very long rotations, postponements in the first thinning, and with increases in stand volume and sequestrated carbon (Table 2, Fig. 3a-c).

In comparison, with a $3 \%$ interest rate, the optimal solutions are CCF, independent of the carbon price (Table 2). Thus, a higher interest rate lengthens the rotation because when CCF is optimal, the NPV increases with rotation length, implying that no optimal RF solutions exist (Section 4, Tahvonen 2015; Tahvonen and Rämö 2016). A higher carbon price lengthens the steady-state harvesting interval and increases the stand volume (Fig. 3a-c, Table 3). It is optimal to thin only large diameter trees (thinning from above), independent of interest rate and carbon price. Including thinning yields major increases in the NPV values, and without carbon pricing and a $1 \%$ interest rate, the increase is from $€ 2164$ to $€ 3882$ (Tables 1 and 2).

Applying the same principles as without thinning, the BLV values with $1 \%$ and $3 \%$ interest rates equal $€ 2679$ and $-€ 1029$, respectively (without externalities $€ 3837$ and $-€ 400$ ). The average annual net timber revenues with a $1 \%$ interest rate are $€ 63$ ha ${ }^{-1}$ and $€ 40 \mathrm{ha}^{-1}$ with a $3 \%$ interest rate. Similarly as without thinning, these figures suggest that we do not underestimate the profitability of

Table 2

Optimal RF and CCF solutions including externalities to reindeer husbandry.

\begin{tabular}{|c|c|c|c|c|c|c|}
\hline $\begin{array}{l}\text { Interest rate, } \\
\%\end{array}$ & $\begin{array}{l}\text { Carbon price, } \\
€ C \mathrm{O}_{2}^{-1}\end{array}$ & $\begin{array}{l}\text { NPV, } € \\
\text { ha }^{-1}\end{array}$ & $\begin{array}{l}\text { NPV, pure timber production, } \\
€ \text { ha }^{-1}\end{array}$ & $\begin{array}{l}\text { Discounted } \mathrm{CO}_{2} \text { sequestration, } \\
\mathrm{tCO}_{2} \mathrm{ha}^{-1}\end{array}$ & $\begin{array}{l}\text { Mean yield, } \\
m^{3} h a^{-1} a^{-1}\end{array}$ & $\begin{array}{l}\text { Rotation, } \\
\text { years }\end{array}$ \\
\hline \multirow[t]{3}{*}{1} & 0 & $-/ 3882$ & $-/ 4938$ & $-/ 65$ & $-/ 1.6$ & $-/ \infty$ \\
\hline & 20 & $\begin{array}{l}5328 / \\
5300\end{array}$ & $4931 / 4855$ & $78 / 75$ & $2.2 / 1.5$ & $245 / \infty$ \\
\hline & 40 & $\begin{array}{l}7034 / \\
6972\end{array}$ & $4464 / 4388$ & $93 / 91$ & $2.1 / 1.5$ & $250 / \infty$ \\
\hline \multirow[t]{3}{*}{3} & 0 & $-/ 174$ & $-/ 803$ & $-/ 30$ & $-/ 1.3$ & $-/ \infty$ \\
\hline & 20 & $-/ 776$ & $-/ 784$ & $-/ 31$ & $-/ 1.6$ & $-/ \infty$ \\
\hline & 40 & $-/ 1443$ & $-/ 609$ & $-/ 37$ & $-/ 1.4$ & $-/ \infty$ \\
\hline
\end{tabular}

Note: Values given as RF/CCF, NPV = net present value.

(a)

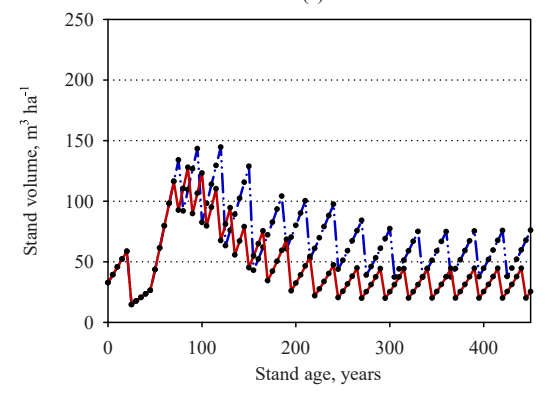

(b)

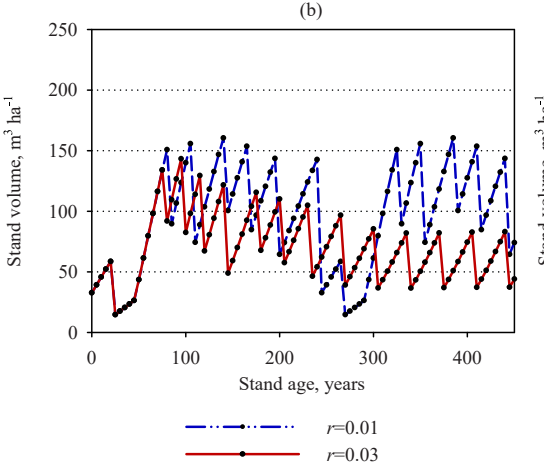

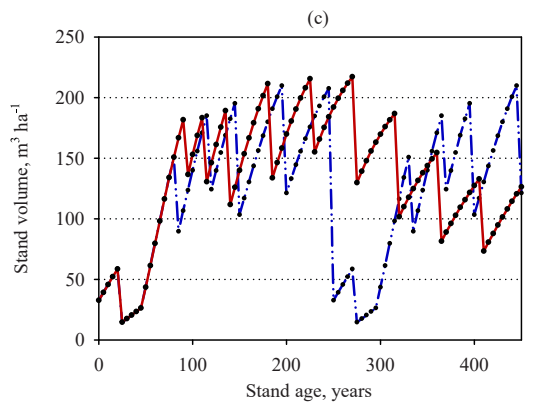

Fig. 3. a-c. Optimal solutions with $€ 0 \mathrm{tCO}_{2}^{-1}$ (a), $€ 20 \mathrm{tCO}_{2}{ }^{-1}$ (b), and $€ 40 \mathrm{tCO}_{2}{ }^{-1}$ (c) carbon prices, for $1 \%$ and $3 \%$ interest rates, external effects on reindeer husbandry included.

Table 3

Optimal CCF steady states.

\begin{tabular}{|c|c|c|c|c|c|c|c|c|c|}
\hline $\begin{array}{l}\text { Interest } \\
\text { rate, } \%\end{array}$ & $\begin{array}{l}\text { Carbon } \\
\text { price, } € \\
\text { tCO }_{2}{ }^{-1}\end{array}$ & $\begin{array}{l}\text { Mean } \\
\text { annual } \\
\text { yield, } \mathrm{m}^{3} \\
\text { ha }^{-1}\end{array}$ & $\begin{array}{l}\text { Mean annual } \\
\text { timber } \\
\text { revenues, } € \\
\text { ha }^{-1}\end{array}$ & $\begin{array}{l}\text { Size of } \\
\text { harvested } \\
\text { trees, cm }\end{array}$ & $\begin{array}{l}\text { Number of } \\
\text { trees before/ } \\
\text { after harvest }\end{array}$ & $\begin{array}{l}\text { Basal area } \\
\text { before/after } \\
\text { harvest, } \mathrm{m}^{2} \\
\mathrm{ha}^{-1}\end{array}$ & $\begin{array}{l}\text { Mean stand } \\
\text { volume, } \mathrm{m}^{3} \\
\text { ha }^{-1}\end{array}$ & $\begin{array}{l}\text { Sawlog ratio } \\
\text { of harvested } \\
\text { trees, \% }\end{array}$ & $\begin{array}{l}\text { Harvest } \\
\text { interval, } \\
\text { years }\end{array}$ \\
\hline \multirow[t]{3}{*}{1} & 0 & 1.6 & 45 & $25.0-39.9$ & $354 / 283$ & $10.3 / 5.2$ & 56 & 57 & 30 \\
\hline & 20 & 1.5 & 47 & $25.0-39.9$ & $368 / 270$ & $12.5 / 5.0$ & 66 & 54 & 45 \\
\hline & 40 & 1.5 & 45 & $30.0-39.9$ & $373 / 284$ & $15.3 / 7.1$ & 92 & 48 & 55 \\
\hline \multirow[t]{3}{*}{3} & 0 & 1.3 & 34 & $20.0-39.9$ & $323 / 248$ & $6.0 / 3.2$ & 32 & 60 & 25 \\
\hline & 20 & 1.6 & 46 & $25.0-39.9$ & $359 / 279$ & $11.1 / 5.1$ & 60 & 56 & 35 \\
\hline & 40 & 1.4 & 39 & $35.0-39.9$ & $364 / 303$ & $16.6 / 9.9$ & 112 & 46 & 45 \\
\hline
\end{tabular}


pure timber production in Upper Lapland.

In their study, Sandström et al. (2016) find that in Swedish Lapland, logging explains the degradation of reindeer pastures instead of variations in reindeer densities. As one solution, they propose CCF but offer no further analysis. According to our results, CCF becomes optimal even without including the externalities on reindeer husbandry if the interest rate is $2-3 \%$ or higher. Including the externalities, CCF becomes competitive even with a 1\% interest rate (Table 2). According to the data in Sandström et al. (2016), a basal area between $10-15 \mathrm{~m}^{2}$ is optimal for lichen growth and excessive stand density followed by regeneration activities (e.g. seed trees) is one main problem in managed forests. Albeit CCF produces open pine forests that are most favorable as reindeer pastures, the solutions that aim to maximize timber revenues do not fully coincide with stand densities of $10-15 \mathrm{~m}^{2}$, suggesting that CCF should at least partly be adjusted for the purposes of reindeer husbandry (Table 3). This would be in line with objectives to increase carbon storage. Increasing large-diameter trees may also contribute to natural regeneration and the abundance of arboreal lichen.

\subsection{Conventional forest management}

We proceed to study conventional forest management by following the silvicultural guidelines for public lands in the Sàmi homeland region (Metsähallitus 2014). Given the guidelines and applying our growth model, the stand is thinned at the age of 80 years, which decreases the basal area from $21.2 \mathrm{~m}^{2} \mathrm{ha}^{-1}$ to $14.0 \mathrm{~m}^{2}$ ha ${ }^{-1}$. According to instructions, the thinning is from below and the number of trees is decreased from 1333 to 464 and the average arithmetic diameter increases from $13.2 \mathrm{~cm}$ to $19.2 \mathrm{~cm}$. Seedling felling is carried out at a stand age of 105 years when the average arithmetic diameter is $22.8 \mathrm{~cm}$ (basal area-weighted average diameter equals $25.9 \mathrm{~cm}$ ). The conventional management produces a mean annual yield of $2.2 \mathrm{~m}^{3} \mathrm{ha}^{-1}$, which is slightly lower than in the optimal RF solutions with thinning, without externalities and $1 \%$ interest rate $\left(2.4-2.5 \mathrm{~m}^{3} \mathrm{ha}^{-1}\right)$.

As shown in Fig. 4a, following conventional guidelines implies that the immediate net revenues from thinning are negative. As thinning is targeted to small size classes, the average harvesting costs are $€ 12.1 / \mathrm{m}^{3}$, which are higher compared to the optimal (thinning from above) solutions $\left(€ 8.0 / \mathrm{m}^{3}\right)$, but rather close to the average reported harvesting costs in Finland $\left(€ 10.59 / \mathrm{m}^{3}\right)$ (Strandström 2018).

The NPVs from conventional management, $€ 3010$ and $€ 530$ with interest rates of $1 \%$ and $3 \%$, are lower than in the economically optimal solutions with and without optimized thinning. This is not a surprise because economic studies have found thinning from above to be economically superior to thinning from below (Tahvonen et al., 2013). With a 3\% interest rate, the NPV remains positive but only due to the discounted net revenues of $€ 722$ from harvesting the initial seedling trees at year 25. The BLVs from conventional management equal $€ 1807$ and $-€ 673$ with interest rates $1 \%$ and $3 \%$. The average annual net revenue is $€ 44$ ha $^{-1}$, which is still above the empirical estimate of $€ 33-36$. The BLV is zero when interest rate is $1.9 \%{ }^{3}$ This is the internal rate of return for investments in continuing timber production in the form of seedling felling and other regeneration actions.

Given $1 \%$ and $3 \%$ interest rates, the values of carbon sequestration with conventional management are $p_{c} \times 28.6 t C O_{2} h a^{-1}$ and $p_{c} \times 56 t \mathrm{CO}_{2} h a^{-1}$, i.e. lower than in any of the optimal solutions with or without thinning (Tables 1 and 2). Fig. 4c shows that the carbon stored in products releases rapidly after thinning because thinning only produces pulpwood (Fig. 4b). In contrast, carbon remains in products much longer after the seedling felling where all but the 80 seed trees are harvested, (Fig. 4c). In sum, the carbonstoring properties of conventional forest management are low.

When the external cost to reindeer husbandry is included, the NPV decreases by $€ 1629$ and $€ 659$ with interest rates $1 \%$ and $3 \%$, respectively, implying that the NPV falls below zero with a $3 \%$ interest rate and without the value of carbon storage. The BLVs are $€ 178$ and $-€ 1332$ given the $1 \%$ and $3 \%$ interest rates.

\subsection{Value of old-growth stands}

Thus far, we have applied the common assumption in optimal rotation models that the initial forest state is the state at the beginning of the rotation period. Next, we take the initial forest state to represent an existing old-growth natural forest in Upper Lapland. Data for this purpose are from the Multi-Source National Forest Inventory (Tomppo et al., 2008; Paikkatietoikkuna 2017). We choose three sites with high densities in the Inari municipality area and compute their average standing volumes of commercial timber. This yields $49 \mathrm{~m}^{3}$ of saw timber, $106.3 \mathrm{~m}^{3}$ of pulpwood, and $13.7 \mathrm{~m}^{3}$ of birch per hectare. Given a seedling felling and following the instructions for conventional forest management (Metsähallitus 2014), the residual stand consists of 80 seed trees (pine), $20.3 \mathrm{~m}^{3}$ of saw timber, and $12.5 \mathrm{~m}^{3}$ of pulpwood. Data on the size structure of existing stands are not available, but an approximate value of the seedling felling is obtained by applying the stumpage prices in Appendix A, Table A3. Given an old-growth as the initial state, we assume that the seed trees are at a state where growth is negligible, and given conventional forest management after the seedling felling, as explained in Fig. 4 a-c, we obtain the outcome shown in Table 4 and Fig. 5.

The seedling felling yields immediate revenues of $€ 2213$, and after this the NPVs from pure timber production are $€ 2554$ and $€ 251$ with $1 \%$ and $3 \%$ interest rates. Thus, converting old-growth to timber production yields net revenues of $€ 4767$ or $€ 2464$ depending on the discount rate. Thus, there is no question whether the conversion of old-growth forest to timber production would not pay off when evaluated with a pure timber NPV. However, the BLV values are $€ 1351$ and $-€ 952$. The BLV is zero when interest rate equals $1.5 \%$. ${ }^{4}$

\footnotetext{
$\overline{3}-1203+\left(-169-385 b^{25}+1512 b^{25}-581 b^{80}+4275 b^{105}\right)\left(1-b^{105}\right)^{-1}=0$ when $b=1 / 1.01857$.

${ }^{4} .-1203-169-385 b^{25}+927 b^{25}-581 b^{80}+4275 b^{105}+b^{105}\left(-169-385 b^{25}+1512 b^{25}-581 b^{80}+4275 b^{105}\right)\left(1-b^{105}\right)^{-1}=0$ when $b \approx 1 /$ $(1+0.015)$.
} 
(a)

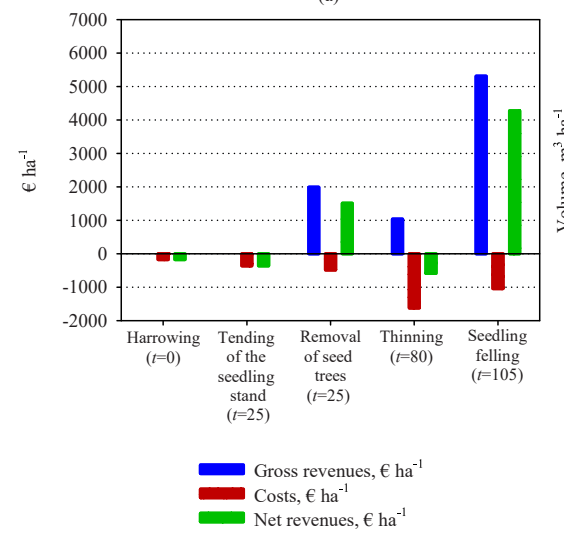

(b)

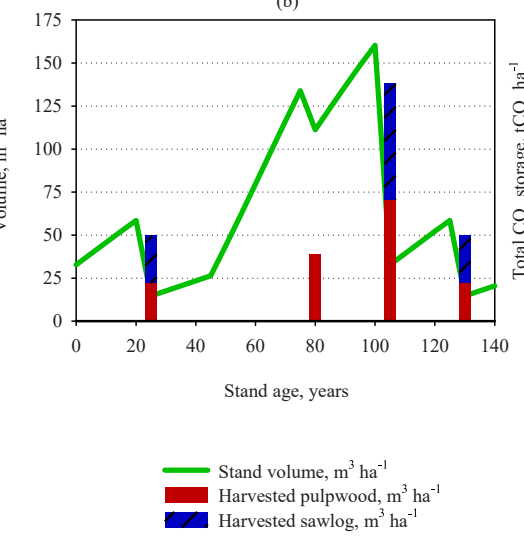

(c)

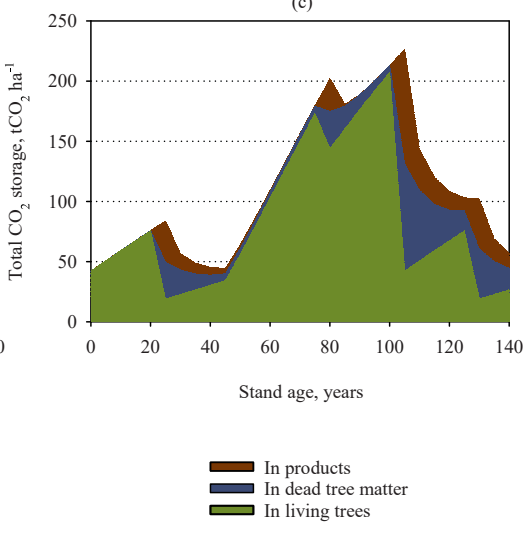

Fig. 4. a-c: Revenues and costs (a), stand volume development (b), and carbon storage development (c) in conventional forest management.

Table 4

Economic consequences of conventional management applied to old-growth stands, $€ \mathrm{ha}^{-1}$.

\begin{tabular}{|c|c|c|c|c|c|c|c|}
\hline $\begin{array}{l}\text { Interest } \\
\text { rate, } \%\end{array}$ & $\begin{array}{l}\text { Price of } \\
\text { carbon, } € \\
\mathrm{tCO}_{2}{ }^{-1}\end{array}$ & $\begin{array}{l}\text { Immediate timber } \\
\text { revenues from } \\
\text { seedling felling }\end{array}$ & $\begin{array}{l}\text { NPV of carbon } \\
\text { emission costs } \\
\text { from seedling } \\
\text { felling }\end{array}$ & $\begin{array}{l}\text { NPV of timber } \\
\text { production after } \\
\text { seedling felling }\end{array}$ & $\begin{array}{l}\text { NPV of carbon } \\
\text { storage after } \\
\text { seedling felling }\end{array}$ & $\begin{array}{l}\text { NPV of } \\
\text { externalities to } \\
\text { reindeer } \\
\text { husbandry }\end{array}$ & $\begin{array}{l}\text { NPV of old-growth } \\
\text { conversion with/ } \\
\text { without externalities }\end{array}$ \\
\hline \multirow[t]{3}{*}{1} & 0 & 2213 & 0 & 2554 & 0 & -1628 & $3139 / 4767$ \\
\hline & 20 & 2213 & -3234 & 2554 & 1048 & -1628 & $953 / 2581$ \\
\hline & 40 & 2213 & -6467 & 2554 & 2095 & -1628 & $-1233 / 395$ \\
\hline \multirow[t]{3}{*}{3} & 0 & 2213 & 0 & 251 & 0 & -659 & $1805 / 2464$ \\
\hline & 20 & 2213 & -2909 & 251 & 448 & -659 & $-656 / 3$ \\
\hline & 40 & 2213 & -5818 & 251 & 897 & -659 & $-3116 /-2415$ \\
\hline
\end{tabular}

Note: NPV $=$ net present value.

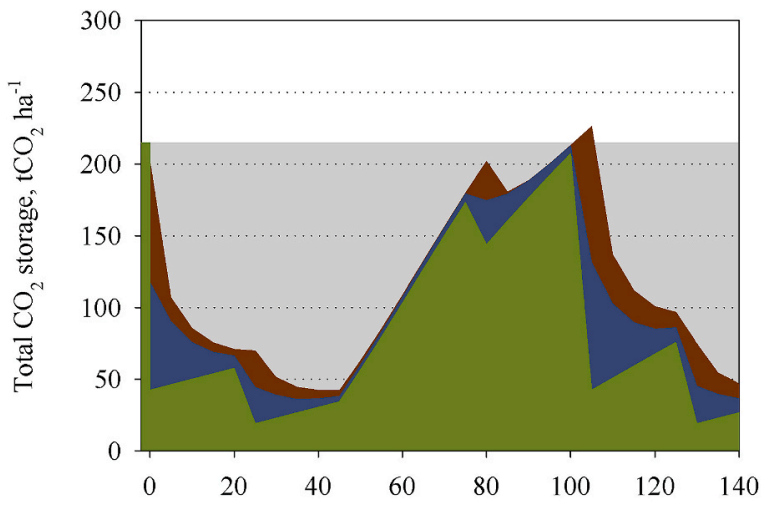

Stand age, years

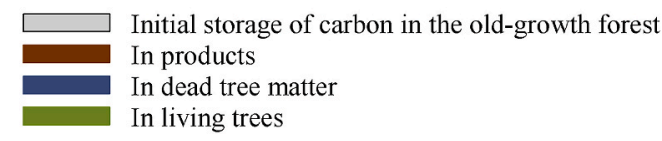

Fig. 5. Development of carbon pool when converting old-growth to conventional forestry.

which represents the internal rate of return from continuing timber production after the initial felling.

The seedling felling decreases carbon storage, and the length of the whole rotation is needed before the initial storage is restored, as shown in Fig. 5. Depending on the interest rate and the social price of carbon, the economic cost of this decrease in carbon storage is high even net of carbon storage that occurs after seedling felling (Table 4). Because a higher interest rate increases the relative weight of the early cost of carbon emissions, increasing the interest rate increases the negative economic effect of the initial carbon release 
Table 5

Profitability of timber production without carbon sequestration.

\begin{tabular}{|c|c|c|c|c|c|c|c|c|}
\hline \multirow[b]{2}{*}{ Solution type } & \multicolumn{4}{|c|}{ Without externalities } & \multicolumn{4}{|c|}{ With externalities } \\
\hline & NPV $1 \%$ & NPV $3 \%$ & BLV $1 \%$ & BLV 3\% & NPV $1 \%$ & NPV $3 \%$ & BLV $1 \%$ & BLV 3\% \\
\hline No thinning & 3728 & 631 & 2525 & -572 & 2164 & -39 & 961 & -1242 \\
\hline Optimal thinning & 5040 & $803^{*}$ & 3837 & $-400 *$ & $3882^{*}$ & $174^{*}$ & $2679 *$ & $-1029 *$ \\
\hline Conventional management & 3010 & 530 & 1807 & -673 & 1381 & -129 & 178 & -1332 \\
\hline Old-growth conversion to conventional management & 4767 & 2464 & 1351 & -952 & 3139 & 1805 & -277 & -1611 \\
\hline Old-growth conversion to optimized management & 6797 & $2737^{*}$ & 3381 & $-679 *$ & $5639^{*}$ & $2108^{*}$ & $2223^{*}$ & $-1308 *$ \\
\hline
\end{tabular}

Note: all figures in $€ \mathrm{ha}^{-1}{ }^{*}{ }^{*}=$ management regime is CCF.

from seedling felling. Thus, higher interest rate and carbon price cause the NPV of the conversion of old-growth to conventionally managed timber production to turn negative with and without the externalities on reindeer husbandry (far right column, Table 4).

As a comparison, we compute the outcomes of the land conversion if, instead of conventional forest management, harvesting after seedling felling continues according to the optimal solutions in Table 2. After taking into account that the growth of seed trees from old-growth is negligible, the outcome with a $3 \%$ interest rate, $€ 40$ carbon price, and without and with reindeer husbandry externalities are $-€ 2059$ and $-€ 2688$, respectively. If carbon price is $€ 20$, the outcome is positive without externalities (€306) and negative with externalities (-€323), while the outcomes remain positive with an interest rate of $1 \%$.

\subsection{Forest mining and forest capital mining}

Table 5 collects the profitability results without carbon sequestration. The results show that without externalities the BLV changes its sign between $1 \%$ and $3 \%$ interest rate in all cases analyzed. Negative BLV implies that from the viewpoint of maximizing the pure net timber revenues, the optimal solution would be a clearcut without any investments on future timber production. Such solutions are sometimes called "forest mining", and in subarctic Upper Lapland conditions, a clearcut without regeneration activities may well imply permanent loss of forest cover.

However, Finnish forest legislation rules out forest mining by requiring that 1200 vigorous seedlings must be generated within 25 years after a clearcut or seedling felling (Forest Decree, 2020/2013). Given this restriction, the second-best solution is to continue timber production instead of abandoning a stand, assuming that the revenues from a clearcut or seedling felling cover the necessary regeneration costs. Given our results and excluding externalities, this condition is met. When the initial state is an old-growth stand, the initial seedling felling yields $€ 2213$ and NPV remains positive independent of the interest rate and, in particular, with the 5.6\% target (and actual) rate of return of the organization managing public lands (Metsähallitus 2019). ${ }^{5}$ However, this profitability is possible only because of the initial forest capital, which in the case of old-growth typically exists without human effort. Given an interest rate above 1.5\%, implying negative BLV, harvesting the initially existing trees may be labelled as "mining of forest capital", as timber production besides the initially existing trees yields only a negative present value of net revenues.

When the external effects of seedling felling on reindeer husbandry is included, the NPVs with a 1\% interest rate show a positive sign (Table 5) but fall below zero with an interest rate of $3 \%$ or higher in cases without thinning (-€39) and conventional management/ initial state with seed trees $(-€ 129)$. The BLVs are negative in all cases with a $3 \%$ interest rate and with $1 \%$ when the origin of seed trees is an old-growth and the management is conventional.

\subsection{Forestry without timber production?}

As shown numerically in Van Kooten et al. (1995) and analytically in Tahvonen and Rautiainen (2017), a high enough carbon price implies (without thinning) that rotation period approaches infinity and it becomes optimal to use forests for carbon storage only. Given the setup of Upper Lapland, these choke prices are $€ 60$ (interest rate 1\%) and $€ 40$ (interest rate 3\%) when thinning is excluded and decrease $€ 5$ after including the externalities on reindeer husbandry (Table 6). Optimized thinning increases the choke prices to $€ 100$ and $€ 60$ depending on the interest rate.

The choke prices are lower when the initial state is an old-growth forest because the net revenues from the seedling felling are lower compared to the case where the stand in seedling felling is a managed forest. Additionally, conventional management does not react to carbon sequestration and choke prices decrease compared to prices based on optimization. Thus, with a $3 \%$ interest rate the choke prices are $€ 20$ or $€ 14$ depending on the inclusion of externalities to reindeer husbandry.

If the interest rate is $3 \%$, externalities on reindeer husbandry are included and the carbon price is between $€ 14$ and $€ 42$, it is preferable not to convert an old-growth forest to timber production, but if a stand is already in timber production, continuing forestry is preferable. Similar results can be obtained when timber production is optimized instead of conventional management. The reason behind this result is that an old-growth may store a high carbon stock that is released in the clearcut of seedling felling albeit the commercial value of timber would be low (high fraction of pulpwood). Thus, the initial stand state may have qualitative implications on optimal long-term management choices (cf. Strang 1983; Tahvonen 2015).

\footnotetext{
${ }^{5}$ In their 2018 report, the state auditors criticized the unclear origin of the rate of return figures given by Metsähallitus (Valtiontalouden tarkastusvirasto 2018).
} 
Table 6

Carbon choke prices. $€ t \mathrm{CO}_{2}^{-1}$

\begin{tabular}{|c|c|c|c|c|c|c|c|c|}
\hline \multirow[b]{2}{*}{ Interest rate } & \multicolumn{2}{|c|}{ No thinning } & \multicolumn{2}{|c|}{ Optimal thinning } & \multicolumn{2}{|c|}{ Conventional management } & \multicolumn{2}{|c|}{ Conventional management, old-growth } \\
\hline & $1 \%$ & $3 \%$ & $1 \%$ & $3 \%$ & $1 \%$ & $3 \%$ & $1 \%$ & $3 \%$ \\
\hline Choke price of carbon & $60 / 55$ & $40 / 35$ & $100 / 100$ & $60 / 60$ & $77 / 60$ & $49 / 42$ & $44 / 29$ & $20 / 14$ \\
\hline
\end{tabular}

Note: Without/with externalities to reindeer husbandry.

(a)

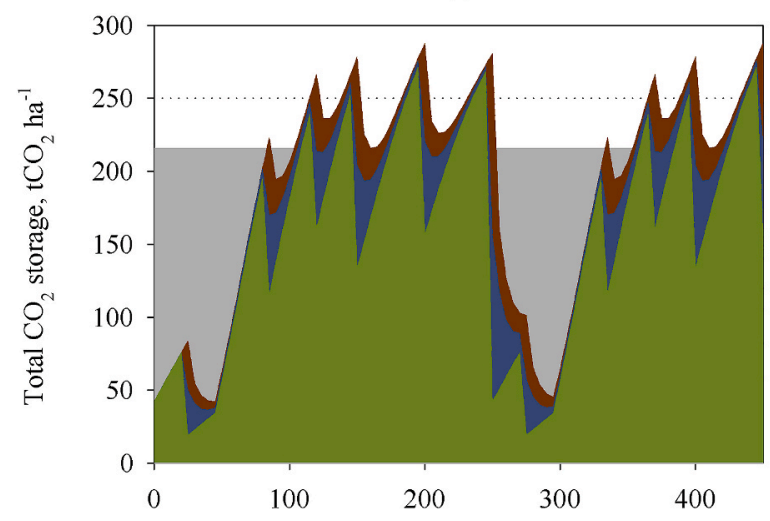

Stand age, years (b)

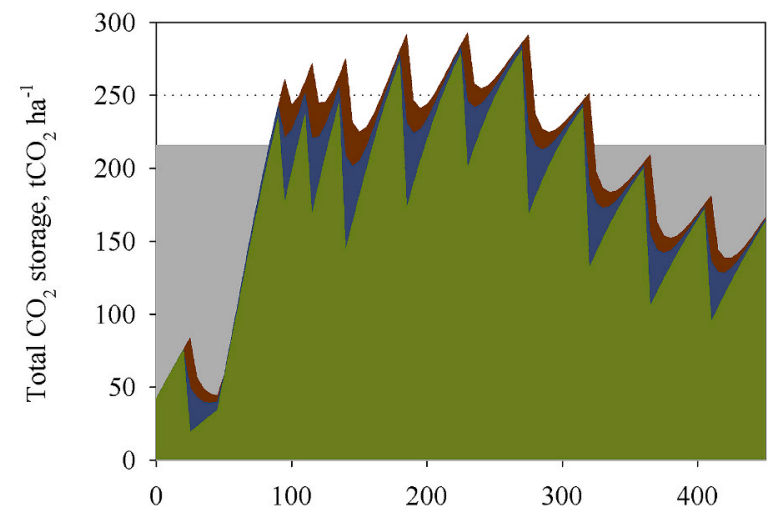

Stand age, years

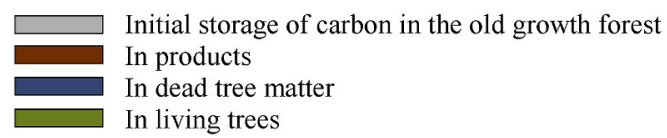

Fig. 6. a,b. Carbon storage development in the optimal solutions with $€ 40 \mathrm{tCO}_{2}{ }^{-1}$ carbon price, external effects on reindeer husbandry and with $1 \%$ (a) and $3 \%$ (b) interest rates.

An established analysis of the conversion of old-growth forests to timber production is developed in a large literature following Fargione et al. (2008). Key concepts in these studies are carbon debt and payback period. The former refers to the fact that clearcutting a natural forest yields an initial rapid release of $\mathrm{CO}_{2}$ into the atmosphere, which is repaid during the payback period by biofuel production and the resulting hypothetical substitution of fossil fuels. A large number of studies have computed estimates for payback times, and e.g. the payback time for Canadian boreal forest may vary between 93 and 757 years in Malcolm et al. (2020) depending for example on the assumptions of the substituted fossil fuel type. As stated by Malcolm et al. (2020), a long payback period is taken to mean that old-growth forest should be conserved from land conversion to timber production.

We study a similar conversion problem as Malcolm et al. (2020) by applying an economic setup that integrates the values of wood production, carbon sequestration, and forests as reindeer pastures. One crucial difference is that our setup, instead of assuming a hypothetical substitution of bioenergy for fossil fuels, applies actual data on industrial wood use. The gray areas in Figs. 5 and $6 \mathrm{a}$ and $\mathrm{b}$ show the difference of carbon stock in an initial old-growth forest and carbon pools in standing biomass, deadwood, and wood products after land conversion. The average carbon storage level may remain below the carbon level in the old-growth, but this, as such, does not show whether the conversion of old-growth is economically justified.

\section{Conclusion}

The prevailing conflict between forestry and reindeer husbandry may be clarified by estimates on the private and social profitability of forestry, which, however, have not been available until the present. Our results suggest that profitability is low: maximum $\mathrm{BLV}$ is negative already with interest rates below $3 \%$ and both with and without the externalities on reindeer husbandry. Given conventional forest management and old-growth stands, BLVs are negative even with interest rates below $1 \%$. The fact that logging existing old-growth stands generate positive net revenues, albeit exhausts forest capital in one single operation, is the explanation to ongoing public and private forestry. Thus, present forestry, which is regarded as a threat to reindeer husbandry and the Sámi culture, appears economically unwarranted even per se. Including externalities on reindeer husbandry and assuming a 3\% interest rate, the economic outcome of old-growth conversion to conventional timber production is reduced to negative. This outcome is sharpened when the analysis includes carbon sequestration: a low or moderate social price of carbon is enough to imply that preserving oldgrowth outperforms land conversion to timber production. One way forward is to develop CCF that could maintain favorable 
pasture conditions and which, according to our results, is economically superior or fully competitive compared to conventional forest management.

Political slowness to find solutions to the reindeer husbandry - forestry trade-off has widened the conflict to private lands. Industrial firms buying timber must cope with certification, i.e. FSC-controlled wood requirements (Forest Stewardship Council 2017). These are not met in areas where the Sámi community states that forestry is a threat to their livelihood and culture. As a side effect, timber purchases from certain private lands have ceased, causing economic losses to private forest owners whose forests then carry out the valuable function for reindeer pastures and carbon storage but without any compensation. One way out of this dead end has been to sell timber from private old-growth forests to local heating plants, a form of wood utilization with much worse carbon emission consequences than in the analysis we present. We have suggested a reconciliation by extending the Finnish payment for ecosystem services program that so far has mainly been applied in southern Finland. From the viewpoint of the Sámi reindeer herders, this program has had a somewhat limited scope, as it aims to protect sites chosen by purely ecological criteria while wider forest multifunctionality is not fully recognized.

Forest multifunctionality includes complexities, and while reindeer husbandry and forestry tend to compete with each other, the setup is different with carbon storage. While earlier studies have shown that a high carbon price may choke off timber production (Van Kooten et al., 1995; Tahvonen and Rautiainen 2017), our results show that the carbon choke price may be lower if the initial state is an old-growth compared to managed stands. In our model, this is a consequence of the growth differences of seed trees, but more generally, old-growth stands may have large numbers of commercially low-value trees and a high carbon release/timber revenue ratio. This should be included in future studies given more detailed data are available compared to our study. Additionally, we suggest an economically explicit approach to studying the rationale of preserving old-growth forest from conversion to timber production (cf. Fargione et al., 2008). This allows, for example, the comparison of the choke price and social price of carbon. The European Commission (2014, p. 80) has projected the EU ETS price to equal €85-€264 tCO2-1 in 2050. Forest carbon is currently not included in ETS, but the carbon price serves as a reference for the actual marginal abatement costs in Finland and the EU. The choke price of $€ 14$ obtained by including the externalities on reindeer husbandry is low compared to these projections and compared to the EU ETS price per $t \mathrm{CO}_{2}$, which has been above $€ 14$ since May 2018. As an EU member state, Finland must abide with the LULUCF regulation. This has proved demanding, and major political effort is used to obtain flexibilities in county-specific regulation. This suggests that the EU requirements, along with the Finnish political target to reach carbon neutrality by 2035, are becoming binding. Thus, preserving the remaining old-growth forests and applying management changes in Upper Lapland may well be both cost-efficient mitigation of climate change and beneficial in improving the conditions of reindeer pastures.

\section{Appendix A}

Table A1

Size-class-specific parameter values for Scots pine.

\begin{tabular}{lllll}
\hline Size classes & $\gamma_{s}$ & $d_{s}$ & $v_{1 s}$ & $v_{2 s}$ \\
\hline 1 & 0.0044 & 75 & 0.01511 & 0 \\
2 & 0.0123 & 125 & 0.07120 & 0 \\
3 & 0.0241 & 175 & 0.14876 & 0.02851 \\
4 & 0.0398 & 225 & 0.13498 & 0.19973 \\
5 & 0.0594 & 275 & 0.19151 & 0.34294 \\
6 & 0.0830 & 325 & 0.37497 & 0.39755 \\
7 & 0.1106 & 375 & 0.55767 & 0.46149 \\
\hline
\end{tabular}

Note: $\gamma_{s}, s=1, \ldots, 7$ is the basal area of a tree $\left(\mathrm{m}^{2}\right), d_{s}, s=1, \ldots, 7$ is the diameter breast height (midpoint) of the size class $(\mathrm{mm}), v_{1 s}, s=1, \ldots, 7$, and $v_{2 s}, s=1, \ldots, 7$ are the pulpwood and sawlog volumes $\left(\mathrm{m}^{3}\right)$ per tree, respectively. The volumes correspond to volumes in Motti stand simulator.

Table A2

Scots pine timber prices in euros per $\mathrm{m}^{3}$.

\begin{tabular}{llll}
\hline & Scots pine, roadside price & Scots pine, stumpage price & Birch, stumpage price \\
\hline Sawlog & 51.0 & 38.0 & 18.7 \\
Pulpwood & 26.2 & 12.2 & 18.7 \\
\hline
\end{tabular}

Note: Prices based on Metsänhoitoyhdistys Ylä-Lappi (2017), Inarin yhteismetsä, 2017, Natural Resources Institute Finland (2020).

\section{Table A3}

Parameter values for the harvesting cost function.

\begin{tabular}{lllllllll}
\hline$i$ & $C_{i 0}$ & $C_{i 1}$ & $C_{i 2}$ & $C_{i 3}$ & $C_{i 4}$ & $C_{i 5}$ & $C_{i 6}$ \\
\hline th & 2.100 & 1.150 & 0.547 & 0.196 & -0.308 & 1.000 & 2.272 \\
$s f$ & 2.100 & 1.000 & 0.532 & 0.196 & -0.308 & 1.000 & 0.535 \\
\hline
\end{tabular}




\section{References}

Ahtikoski, A., Tuulentie, S., Hallikainen, V., Nivala, V., Vatanen, E., Tyrväinen, L., Salminen, H., 2011. Potential trade-offs between nature-based tourism and forestry, a case study in Northern Finland. Forests 2 (4), 894-912.

Amacher, G.S., 2015. The forest harvesting problem: have we reached the limit of our understanding?. In: Handbook on the Economics of Natural Resources. Edward Elgar Publishing.

Assmuth, A., Rämö, J., Tahvonen, O., 2018. Economics of size-structured forestry with carbon storage. Can. J. For. Res. 48 (1), 11-22.

Berg, A., Östlund, L., Moen, J., Olofsson, J., 2008. A century of logging and forestry in a reindeer herding area in northern Sweden. For. Ecol. Manag. 256 (5), 1009-1020.

Bergman, I., Liedgren, L., Östlund, L., Zackrisson, O., 2008. Kinship and settlements: Sami residence patterns in the Fennoscandian alpine areas around AD 1000. Arctic Anthropol. 45 (1), 97-110.

Bjørklund, I., 1990. Sami reindeer pastoralism as an indigenous resource management system in northern Norway: a contribution to the common property debate. Dev. Change 21 (1), 75-86.

Bollandsås, M.O., Buongiorno, J., Gobakken, T., 2008. Predicting the growth of stands of trees of mixed species and size: a matrix model for Norway. Scand. J. For. Res. 23 (2), 167-178.

Bostedt, G., Lundgren, T., 2010. Accounting for cultural heritage-a theoretical and empirical exploration with focus on Swedish reindeer husbandry. Ecol. Econ. 69 (3), 651-657.

European Commission, 2014. Impact Assessment SWD (2014). 15 Final. Accompanying the Document Communication from the Commission to the European Parliament, the Council, the European Economic and Social Committee and the Committee of the Regions. A Policy Framework for Climate and Energy in the Period from 2020 up to 2030. European Commission, Brussels.

European Union, 2005. Treaty Establishing Constitution for Europe, vol. 310. Office for Official Publications of the European Communities, Luxemburg.

Fargione, J., Hill, J., Tilman, D., Polasky, S., Hawthorne, P., 2008. Land clearing and the biofuel carbon debt. Science 319 (5867), $1235-1238$.

Forest decree 1308/2013, 16 June 2020. Retrieved from: https://finlex.fi/fi/laki/alkup/2013/20131308 [In Finnish].

Forest Stewardship Council. Retrieved from. https://fsc.org/en/document-centre/documents/resource/373.18.November.2020.

Hartman, R., 1976. The harvesting decision when a standing forest has value. Econ. Inq. 14 (1), 52-58.

Hyppönen, M., 2002. Lapin metsätalouden erityispiirteet. Metsätieteen aikakausikirja 4/2002, 647-650 [In Finnish].

Inarin yhteismetsä, 2017. Vuosikertomus Tilikaudelta 1.1.2016-31.12.2016 ([Annual financial statement, in Finnish]).

Jonsson Cabrajič, A.V., Moen, J., Palmqvist, K., 2010. Predicting growth of mat-forming lichens on a landscape scale-comparing models with different complexities. Ecography 33 (5), 949-960.

Korosuo, A., Sandström, P., Öhman, K., Eriksson, L.O., 2014. Impacts of different forest management scenarios on forestry and reindeer husbandry. Scand. J. For. Res. 29 (Suppl. 1), 234-251.

Kumpula, J., Colpaert, A., Anttonen, M., 2007. Does forest harvesting and linear infrastructure change the usability value of pastureland for semi-domesticated reindeer (Rangifer tarandus tarandus)?. In: Annales Zoologici Fennici. Finnish Zoological and Botanical Publishing Board, pp. 161-178.

Kumpula, J., Kurkilahti, M., Helle, T., Colpaert, A., 2014. Both reindeer management and several other land use factors explain the reduction in ground lichens (Cladonia spp.) in pastures grazed by semi-domesticated reindeer in Finland. Reg. Environ. Change 14 (2), 541-559.

Lehtonen, A., Mäkipää, R., Heikkinen, J., Sievänen, R., Liski, J., 2004. Biomass expansion factors (BEFs) for Scots pine, Norway spruce and birch according to stand age for boreal forests. For. Ecol. Manag. 188 (1-3), 211-224.

Liski, J., Pussinen, A., Pingoud, K., Mäkipää, R., Karjalainen, T., 2001. Which rotation length is favourable to carbon sequestration? Can. J. For. Res. 31 (11), 2004-2013.

Mäki, O., 2013. Summa-arvo menetelmän aputaulukot [Forest valuation statistics. In: Finnish]. Metsä Kustannus, Metsätalouden Kehittämiskeskus Tapio (Vantaa).

Mäkinen, H., Hynynen, J., Siitonen, J., Sievänen, R., 2006. Predicting the decomposition of Scots pine, Norway spruce, and birch stems in Finland. Ecol. Appl. 16 (5), $1865-1879$.

Malcolm, J.R., Holtsmark, B., Piascik, P.W., 2020. Forest harvesting and the carbon debt in boreal east-central Canada. Climatic Change 161 (3), $433-449$.

Malo, P., Tahvonen, O., Suominen, A., Beck, P., Viitasaari, L., 2021. Reinforcement learning in optimizing forest management. Can. J. For. Res. https://doi.org/ 10.1139/cjfr-2020-0447.

Martin, A.B., Ruppert, J.L., Gunn, E.A., Martell, D.L., 2017. A replanning approach for maximizing woodland caribou habitat alongside timber production. Can. J. For. Res. 47 (7), 901-909.

Matala, J., Hynynen, J., Miina, J., Ojansuu, R., Peltola, H., Sievänen, R., Kellomäki, S., 2003. Comparison of a physiological model and a statistical model for prediction of growth and yield in boreal forests. Ecol. Model. 161 (1-2), 95-116.

Metsähallitus, 2014. Metsänhoito-ohje [silvicultural guidelines, in Finnish]. Retrieved from. https://news.cision.com/fi/metsahallitus. (Accessed 14 September 2017).

Metsähallitus, 2019. Financial statement for 2019. Retrieved from: https://julkaisut.metsa.fi/julkaisut/show/2429. (Accessed 15 November 2020) [In Finnish].

Natural Resources Institute Finland, 2020. Statistics. Natural Resources Institute Finland. https://stat.luke.fi/en/. (Accessed 1 November 2020).

Nurminen, T., Korpunen, H., Uusitalo, J., 2006. Time consumption analysis of the mechanized cut-to-length harvesting system. Silva Fenn. 40 (2), $335-363$.

Paikkatietoikkuna, 2017. Retrieved from: https://kartta.paikkatietoikkuna.fi/?lang=en.26 March 2018.

Palviainen, M., Finér, L., Kurka, A.M., Mannerkoski, H., Piirainen, S., Starr, M., 2004. Decomposition and nutrient release from logging residues after clear-cutting of mixed boreal forest. Plant Soil 263 (1), 53-67.

Palviainen, M., Finér, L., Laiho, R., Shorohova, E., Kapitsa, E., Vanha-Majamaa, I., 2010. Carbon and nitrogen release from decomposing Scots pine, Norway spruce and silver birch stumps. For. Ecol. Manag. 529, 390-398.

Parkatti, V.P., Tahvonen, O., 2020. Optimizing continuous cover and rotation forestry in mixed-species boreal forests. Can. J. For. Res. 50 (11), $1138-1151$.

Parkatti, V.P., Assmuth, A., Rämö, J., Tahvonen, O., 2019. Economics of boreal conifer species in continuous cover and rotation forestry. For. Pol. Econ. 100 , 55-67.

Parks, P.J., Bostedt, G., Kriström, B., 2002. An integrated system for management and policy analysis. Environ. Resour. Econ. 21 (3), $203-220$.

Parrotta, J.A., Trosper, R.L. (Eds.), 2012. Traditional Forest-Related Knowledge. Springer, Dordrecht.

Pekkarinen, A.J., Kumpula, J., Tahvonen, O., 2015. Reindeer management and winter pastures in the presence of supplementary feeding and government subsidies. Ecol. Model. 312, 256-271.

Pekkarinen, A.J., Kumpula, J., Tahvonen, O., 2020. Predation costs and compensations in reindeer husbandry. Wildl. Biol. 2020 (3).

Pihlainen, S., Tahvonen, O., Niinimäki, S., 2014. The economics of timber and bioenergy production and carbon storage in Scots pine stands. Can. J. For. Res. 44 (9), 1091-1102.

Pukkala, T., Lähde, E., Laiho, O., 2013. Species interactions in the dynamics of even-and uneven-aged boreal forests. J. Sustain. For. 32 (4), $371-403$.

Reindeer Husbandry Act 848, 1990. Retrieved from. https://www.finlex.fi/fi/laki/kaannokset/1990/en19900848_20000054.pdf. (Accessed 11 June 2020).

Ruppert, J.L., Fortin, M.J., Gunn, E.A., Martell, D.L., 2016. Conserving woodland caribou habitat while maintaining timber yield: a graph theory approach. Can. J. For. Res. 46 (7), 914-923.

Saijets, J., 2019. Presentation at the Ministry of Environment. November 15, Helsinki.

Salminen, H., Lehtonen, M., Hynynen, J., 2005. Reusing legacy FORTRAN in the MOTTI growth and yield simulator. Comput. Electron. Agric. 49 (1), 103-113.

Samuelson, P.A., 1976. Economics of forestry in an evolving society. Econ. Inq. 14 (4), 466-492.

Sandström, P., Cory, N., Svensson, J., Hedenås, H., Jougda, L., Borchert, N., 2016. On the decline of ground lichen forests in the Swedish boreal landscape: implications for reindeer husbandry and sustainable forest management. Ambio 45 (4), 415-429.

Schuster, R., Germain, R.R., Bennett, J.R., Reo, N.J., Arcese, P., 2019. Vertebrate biodiversity on indigenous-managed lands in Australia, Brazil, and Canada equals that in protected areas. Environ. Sci. Pol. 101, 1-6. 
Shorohova, E., Kapitsa, E., Vanha-Majamaa, I., 2008. Decomposition of stumps 10 years after partial and complete harvesting in a southern boreal forest in Finland. Can. J. For. Res. 38 (9), 2414-2421.

Sinha, A., Rämö, J., Malo, P., Kallio, M., Tahvonen, O., 2017. Optimal management of naturally regenerating uneven-aged forests. Eur. J. Oper. Res. 256 (3), 886-900.

Statistics Finland, 2021. Greenhouse gas emissions in Finland 1990 to 2019. National inventory report under the UNFCCC and the Kyoto Protocol. Retrieved from. https://www.stat.fi/tup/khkinv/khkaasut_raportointi_en.html.

Stevenson, S.K., Coxson, D.S., 2007. Arboreal Forage Lichens in Partial Cuts-A Synthesis of Research Results from British Columbia. Canada. Rangifer, pp. 155-165.

Stevenson, S.K., Coxson, D.S., 2015. Can partial-cut harvesting be used to manage terrestrial lichen habitat? A review of recent evidence. Rangifer 11-26.

Strandström, M., 2018. Timber Harvesting and Long-Distance Transportation of Roundwood 2017. Metsäteho Slides Tuloskalvosarja 8b/2018. Metsäteho Oy.

Strang, W.J., 1983. On the optimal forest harvesting decision. Econ. Inq. 21 (4), 576-583.

Tahvonen, O., 2015. Economics of naturally regenerating, heterogeneous forests. J. Assoc. Environ. Resour. Econ. 2 (2), $309-337$.

Tahvonen, O., Rämö, J., 2016. Optimality of continuous cover vs. clear-cut regimes in managing forest resources. Can. J. For. Res. 46 (7), 891-901.

Tahvonen, O., Rautiainen, A., 2017. Economics of forest carbon storage and the additionality principle. Resour. Energy Econ. 50, $124-134$.

Tahvonen, O., Pihlainen, S., Niinimäki, S., 2013. On the economics of optimal timber production in boreal Scots pine stands. Can. J. For. Res. 43 (8), 719-730.

Tahvonen, O., Kumpula, J., Pekkarinen, A.J., 2014. Optimal harvesting of an age-structured, two-sex herbivore-plant system. Ecol. Model. 272 , 348-361.

Tomppo, E., Haakana, M., Katila, M., Peräsaari, J., 2008. Multi-source National Forest Inventory: Methods and Applications, vol. 18. Springer Science \& Business Media.

Turunen, M.T., Rasmus, S., Järvenpää, J., Kivinen, S., 2020. Relations between forestry and reindeer husbandry in northern Finland-Perspectives of science and practice. For. Ecol. Manag. 457, 117677.

Van Kooten, G.C., Binkley, C.S., Delcourt, G., 1995. Effect of carbon taxes and subsidies on optimal forest rotation age and supply of carbon services. Am. J. Agric. Econ. 77 (2), 365-374.

Yemshanov, D., Haight, R.G., Liu, N., Rempel, R., Koch, F.H., Rodgers, A., 2021. Balancing large-scale wildlife protection and forest management goals with a gametheoretic approach. Forests 12 (6), 809.

Metsänhoitoyhdistys Ylä-Lappi, June 2017. Retrieved from. https://www.mhy.fi/lappi, 6. 